UDC 81.255.4

DOI https://doi.org/10.32841/2409-1154.2021.48-3.13

\author{
Ababilova N. M., \\ Candidate of Pedagogical Sciences, \\ Associate Professor at the Department of Theory and Practice of Translation from English \\ Petro Mohyla Black Sea National University
}

\author{
Usachenko I. V., \\ Senior Lecturer at the Department of Theory and Practice of Translation from English \\ Petro Mohyla Black Sea National University
}

\title{
PECULIARITIES OF POLITICAL SPEECHES TRANSLATION
}

Summary. The article is devoted to the problem of political speeches translation, which is extremely relevant today, as political activity plays a special role in society, affects the country's place in the international arena, its relations with other countries. Through speeches, politicians have the opportunity to appeal to both the international community and their compatriots, gain recognition, demonstrate their leadership and represent their country in the best possible way. Translation of political speeches is considered to be one of the most complicated types of translation, which is the area of increased linguistic responsibility. Considering the role of a translator in the process of political speeches translation, it has been established that a perfect command of the language, relevant vocabulary and terminology, knowledge of the political situation and the ability to properly render it by means of target language will facilitate translation performance at a professional level. When translating political speeches, it is important for a translator to take into account the cultural peculiarities of the countries of the source language and the target one, to know their history, internal political processes, to understand the views of their leaders on specific situations. A translator must clearly formulate and reproduce the intentions of the author of the text or speaker, preserving the informative and expressive functions of a speech. It has been determined that the problem of translation of political speeches is their lexical, grammatical, and stylistic characteristics. Their translation is facilitated by translation strategies, which are regarded as translation methods, which constitute a purposeful system of interrelated techniques that takes into account the type of translation and the appropriate existing methods of translation. Due to differences in the perception of subjects and evaluation of political events, differences in semantic structure or traditional use of words in different languages, literal translation becomes unclear. Translation transformations, which are defined as numerous and qualitatively diverse interlingual transformations, are used to achieve translation equivalence (translation adequacy) despite the differences in the formal and semantic systems of two languages. It has been established that there are several reasons for their use.

Key words: political speech, translation methods, translation strategies, transformations, problems of translation.

Introduction. Our present is a process of constant changes, both socio-cultural and political. These changes contribute to the transformation of the language system, which is constantly evolving and getting accustomed to the socio-political reality that dominates in the use of a particular language. Political texts, namely speeches, play an important role in this process to interest and influence the audience. Translation in the political environment is a task of increased linguistic responsibility and plays an important role in today's political communication processes; in addition, translation is increasingly interpreted as a mechanism for presenting intercultural and socio-political features. An inaccurate, rough translation of a political text can have serious consequences that could damage politician's image, negatively affect the outcome of negotiations and even cause political conflicts.

Analysis of recent researches and publications. In the last decade, the theory of political discourse has become linguists' object of close attention. Politics is carried out through language and, as a consequence, through political discourse. Currently, there is a trend to globalize society. Political speech as a genre of political discourse is an effective means of political influence on citizens, the formation of certain ideas, assessments and attitudes to reality.

Political speeches have become the object of scientific research by E. Benveniste, D. Misyurov, W. Schmidt and other national and foreign scholars.

A. Belova, J. Derrida, A. Greimas, J. Habermas, O. Haidulin, N. Herasymenko, J. Fiske, M. Krongauz, T. Shmelova, E. Zemskaya etc. dealt with the problems of rendering of different types of discourse, political one in particular.

The aim of the article is to analyze the difficulties and peculiarities of political speeches translation into Ukrainian.

For conducting the research, the following methods were used: the general scientific methods of analysis and synthesis (for studying theoretical basis of political discourse translation, its types and challenges for translators' effective work); the inductive method (for generalizing the material and conclusions on the basis of the existing study); the deductive method (for adapting the principles of the general translation theory in the aspect of the suggested investigation). Classification and typological analysis were used to compile and represent the studied material in the form of classifications.

Main material presentation. Political speeches are prepared highly politicized speeches with a positive or negative assessment of social processes, phenomena and their justification, confirmation by specific facts, the prospect of political changes [1]. They almost always belong to publicistic style, which is characterized by the expression of an ideological position, a view of different situations, and the assertion of the idea, which, in its turn, is considered to be the removal of other views, even if they are not mentioned. 
Political speech, as a type of political discourse, is designed to identify the qualities of a leader, present a politician and help him gain recognition. It consists of an introduction, main part and conclusion. In introduction, the speaker appeals to an addressee; in the main part the speaker utters theses and proves his arguments, and in the conclusion, he summarizes and expresses appeals to the audience. The lexical features of political speeches include the use of neutral vocabulary, book vocabulary, terms, and nomenclature vocabulary. Neologisms, euphemisms, foreign words, metaphors and idiomatic expressions are used in political speeches. Regarding grammatical features, it should be noted that the use of the first person singular and plural is common, which causes listener's sense of unity. The use of modal verbs indicates the intentions and requirements of the speaker and subconsciously affects the addressee. Politicians are characterized by the use of simple as well as incomplete sentences, which helps to absorb information better. The use of repetitions and parallel constructions creates a special rhythm of expression and is considered an effective means of influencing the addressee. In political texts, stereotypes and language patterns are usually used, commenting rather than informing prevails.

Thus, the priority task of a translator in the field of politics is the possibility to maximally preserve the desired communicative effect, which can be achieved by a translator, provided the stylistic features, lexical and syntactic means of political speeches are studied.

A translator of political texts must have good background knowledge and a considerable vocabulary, know the peculiarities of the country. And, since political discourse points to the language dynamics, a translator must trace semantic changes within the discourse itself.

A. Fedorov holds to the opinion that the professional qualities of a translator are very important, because he, like no other, must be competent in the political sphere and understand the essence of discussions, because "the main prerequisite for correct translation is knowledge of the subject" [2, p. 204]. When translating political speeches, it is important to take into account not only the context but also the cultural peculiarities of the countries of the source and target languages, to know their history, internal political processes, to understand the views of leaders on specific situations. This means that, firstly, a translator must be well-versed in the basic concepts of political discourse, and secondly, must have the skills to analyze the specifics of their verbalization both in the source and target languages. Compliance with these requirements evidences that the translation of public political texts takes into account the high professionalism and a deep knowledge of a translator in various fields [3].

A translator takes responsibility for the function of the speech unit of the source language he has chosen for this purpose in the target language. It is this equivalent which must perform the same function, i.e. reproduce a mental or emotional load for the recipient.

At each stage of translation of political speeches there are a number of problems. According to L. Venuti, difficulties arise during rendering of colloquial words and expressions, compensation of losses and justification of differences in written translation; there is a disparity in grammatical categories, lexical or morpho-syntactic differences between the source language and the target language; problems of polysemy arise; the author's goal may be lost [4].

The problem of political speeches translation is studied by many scholars. They argue that the greatest difficulty is connected with the translation of lexical units.
P. Newmark considers two reasons for this phenomenon: firstly, a translator does not fully understand the lexical unit (the word in the context has a slightly different meaning or is used in an unusual combination of words), and secondly, a translator has difficulty in choosing the appropriate lexical unit in the target language due to the difference in the semantic range of lexical units in the source and target languages. To avoid certain difficulties while rendering some lexical items, P. Newmark recommends:

- to use loan translation for political jargon;

- to translate a phrase, one should use equivalent, cliché or translate literally;

- to translate euphemisms one should select equivalent in the target language;

- to use semantic translation for metaphors;

- to translate acronyms and abbreviations one should bear in mind contextual factors, i.e. the linguistic and cultural level of readers;

- to translate political realities, it is necessary to use adaptation, i.e. selection or replacement of realia with similar words in the target language;

- to translate culturally marked vocabulary one should use omission, substitution, explication, adaptation [5].

In order to avoid ambiguity and confusion of content, when translating complex syntactic constructions, it is recommended to divide complex sentences into shorter ones.

A translator is forced to preserve an informative and expressive function in the socio-political text. To do this, he must correctly render the communicative intention of the author of the original, understand the purpose of communicative influence on the audience, and find out what communicative effect the original text has on the reader; when translating into the native language a translator must choose language means to achieve the same communicative effect the author of the original text caused being perceived by a foreign reader [6].

N. Geiko studied rendering of socio-political texts and developed recommendations for their translation [7]. Thus, before translating a text, it is necessary to analyze it, which will help a translator to understand the content of the text as a whole, see its structure, clarify linguistic and extralinguistic parameters, identify lexical units that sometimes need to be checked and pay more attention to their content during translation. No less important is the stage of developing a specific translation strategy. The next step is to most accurately select the equivalent to reveal the meaning of lexical units. After all, many of them have culturally specific features, and some even require using additional sources of information. When performing the translation itself, a translator must follow such recommendations:

1) avoid unnecessary or repetitive words; compare both texts during translation, pay attention to the peculiarities of keywords, pay attention to functional words that convey the emotional mood of the text and serve to connect words;

2) translating the names of political organizations, take care to preserve their equivalents natural for the target language, and in case of their absence independently create an equivalent that fully reveals the meaning of the lexical unit;

3) preserve the imagery and color of the source text in the target text. Translating real facts (words and expressions related to historical events, the peculiarities of social and political life of the country of the source language), take care of the maximum 
possible preservation of national features and identity and take into account the norms of the target language.

With knowledge of linguistic and cultural features, it is much easier for a translator to carry out translation activities and solve complex problems, namely to follow the pragmatics of the text, reproduce the main functions of socio-political text, preserve evaluative properties of words, choose politically correct statements.

Translating pseudo-international vocabulary, a translator should carefully study the lexical content of the text, find pseudointernationalisms in it and find out possible variants of their translation, presented in a specialized dictionary; find out the context in which the word is used; check the available equivalents in bilingual dictionaries (for example, the ABBYY Lingvo electronic dictionary). To translate terms related to political and state life, one should use lexical equivalents, transcription, loan translation, descriptive translation. Rendering neologisms that reflect socio-political processes, it is recommended to use transcription, transliteration and descriptive translation. Abbreviations, if they are not common, are expanded during translation; lexical equivalents as well as loan translation are also used. It is desirable to preserve figurative comparisons, metaphors and other stylistic devices during translation, most often they are rendered by means of lexical equivalents, loan translation, logical development, total reorganization.

It should be noted that to correctly construct the target text, translation strategies are used, which are regarded as translation methods, which constitute a purposeful system of interrelated techniques that takes into account the type of translation and the appropriate existing methods of translation [8] and "translator's plan of consecutive actions aimed at translation of a specific text", which has a specific key goal achieved through the use of all important principles and parameters of clearly structured translation circumstances [9, p. 156].

According to V. Komissarov, translator's strategy covers three groups of general principles of the translation process: some initial principles, the choice of the general course of action a translator will be guided by in case of making specific decisions; choice of the type and sequence of actions in the translation process. The researcher notes that the most important strategic principle of a translator is to be critical of his work in order to find the best variant of translation. Factors that determine the choice of a specific translation strategy include: purpose of the translation, type of text being translated, and target audience. Based on a combination of these factors, the necessary translation decisions are made.

Thus, translation strategy is a general translation approach, the aim of which is to adequately render the source language into the target language, taking into account the speaker's cultural, social and political peculiarities.

The most common option for understanding translation strategies is considered to be translation transformations, variants for finding means of translation to render the content of the text.

The main task in the translation of political speeches is to convey its content to the audience in the most adequate, clear and understandable form because the main purpose of translation is to achieve adequacy. When achieving the adequacy of translation, such translation transformations should be skillfully used in order to convey the source text as accurately as possible, in compliance with all relevant norms. One of the tasks of a translator of political speeches, in addition to the accurate, adequate and clear translation of content, is to convey all the emotional characteristics of the source language to the audience, especially their political orientation. As for the translation of facts in political speeches, there are no special problems and they are often used in the literal sense. Of course, a sentence can change its structure when translated, but this does not affect the meaning in the target language. But everything is different with texts that contain means of expression. Such texts belong in most cases to female politicians rather than male politicians, and are characterized by imagery, full of feelings and experiences.

According to S. Maksimov, the most complete reproduction of information is possible through the use of certain structural or semantic changes, which are called transformations in translation [1]. Although translation transformations are an integral part of the translation process and it is impossible to achieve adequate translation without them, there is currently no universal definition of this concept. Thus, translation transformations are defined differently in the following way:

- "techniques of logical thinking, by means of which we reveal the meaning of a foreign word in context and find a Russian equivalent for it that does not coincide with the lexical one" (Ja. Retsker) [10];

- "the basis of most translation techniques, which is changing the formal (lexical or grammatical transformations) or semantic (semantic transformations) components of the source text while preserving the information intended for rendering" (R. MinyarBeloruchev) [8];

- "interlingual operations of meaning reexpression" (A. Shveitser) [11];

- "interlingual transformations to achieve equivalence of the source and target texts (in order to preserve the functional impact of the message)" (0. Semenov) [12].

- "translation techniques, which consist of replacing permanent equivalents with non-permanent ones", as well as "linguistic expressions themselves obtained as a result of the use of such techniques" (A. Arkhipov) [13].

The use of transformations is due to several reasons, namely: differences in the systems of the source and target languages, i.e. in one of the languages there may be no category inherent in another language; classifications may differ within the same category; comparable linguistic categories do not completely coincide in meaning; differences between the norms of the source and target languages, i.e. we face a non-observance of the norm in the case when the essence of the statement is clear, but it causes the idea of incorrectness of language (norm divergences); differences between the usus of the source and target languages (usus is the rules of situational usage of language; it reflects the language habits and traditions of the language group) [14].

The above-mentioned creates difficulties in translation, which are overcome by means of translation transformations as a way to achieve equivalence in translation, particularly in the translation of political speeches.

Conclusions. Translation is a complex process of interpreting the meaning of a text embedded in the original. A translator is responsible for preserving the desired communicative result by investigating lexical, syntactic and stylistic features. When translating political speeches, it is necessary to have background knowledge, cultural features of countries, domestic political processes, to know the history of countries. Difficulties in translation are due to differences in grammatical, lexical, syntactic categories, problems of polysemy and the possible loss of author's goal. When translating political speeches, a translator must remember that he 
must convey their content to the addressee in an understandable and adequate form, as well as use translation transformations to convey the source text as accurately as possible.

\section{References:}

1. Максімов C.Є. Практичний курс перекладу (англійська та українська мови). Київ : Ленвіт, 2006. 157 с.

2. Федоров А.В. Основы общей теории перевода (лингвистические проблемы). СПбГУ; Москва : ФИЛОЛОГИЯ ТРИ, 2002. 416 с.

3. Корунець І.В. Теорія і практика перекладу (аспектний переклад). Вінниця : Нова Книга, 2003. 445 с.

4. Venuti L. The translation studies Reader. Routledge, 2000. 524 p.

5. Newmark P. Textbook of Translation. Prentice Hall, 1991. 184 p.

6. Комиссаров В.Н. Общая теория перевода. Москва : ЧеРо : Юрайт, 2000. 132 с

7. Гейко Н.Р. Общественно-политическая лексика. Костанай : Костанайский филиал ФГБОУ ВПО «ЧелГУ», 2013. 166 с.

8. Миньяр-Белоручев Р.К. Общая теория перевода и устный перевод. Москва : Воениздат, 1980. 237 с.

9. Бурукина О.А. Коннотативность как универсальное свойство языка и дискурса. Вестник. Серия: Гуманитарные и сочиальные науки. 2011. № 3. С. 154-158.

10. Рецкер Я.Й. Теория перевода и переводческая практика. Очерки лингвистической теории перевода. Москва : Р. Валент, 2006. 237 с.

11. Швейцер А.Д. Теория перевода. Статус, проблемы, аспекты. Москва : ЛИБРОКОМ, 2009. 216 с

12. Семенов А.Л. Теория перевода : учебник для студентов учреждений высшего профобразования. Москва : Издательский центр «Академия», 2013.224 с

13. Архипов А.Ф. Письменный перевод с немецкого языка на русский. КДУ, 2008. 336 с

14. Латышев Л.К. Перевод: проблемы теории, практики и методики преподавания. Москва : Просвещение. 1998. 160 с.

Абабілова Н. М., Усаченко І. В. Особливості перекладу політичних промов

Анотація. Статтю присвячено проблемі передачі політичних промов, що є вкрай актуальним у наш час, оскіль- ки політична діяльність відіграє особливу роль у житті суспільства, впливає на місце країни на міжнародній арені, iii взаємини $з$ іншими державами. За допомогою промов політики мають можливість звернутися як до міжнародного співтовариства, так і до співвітчизників, здобути визнання, продемонструвати своє лідерство та представити свою країну якнайкраще. Переклад політичних промов вважається одним із найскладніших видів перекладу, що являє собою сферу підвищеної мовної відповідальності. Розглянувши роль перекладача у процесі перекладу політичних промов, встановлено, що досконале володіння мовою, відповідною лексикою та термінологією, знання особливостей політичної ситуації і вміння правильно передати іiі мовою перекладу сприятимуть виконанню перекладу на професійному рівні. Перекладаючи політичні промови, перекладачеві важливо враховувати культурні особливості країн мови оригіналу та перекладу, добре знати їх історію, внутрішні політичні процеси, розуміти погляди лідерів на конкретні ситуації. Перекладач має чітко формулювати і відтворювати інтенції автора тексту або оратора, зберігаючи інформативну та експресивну функції промови. Визначено, що проблему перекладу політичних промов становлять їх лексичні, граматичні та стилістичні характеристики. Їх відтворенню сприяють стратегії перекладу, які трактують як методи перекладу, як цілеспрямовану систему взаємопов'язаних прийомів, яка враховує вид перекладу та закономірні наявні способи перекладу. Через різницю в баченні предметів та оцінюванні політичних подій, відмінності у семантичній структурі або традиційному для кожної мови вживанні слів дослівний переклад стає незрозумілим, у вирішенні цього питання також можуть допомогти перекладацькі трансформації, які розуміють як численні та якісно різноманітні міжмовні перетворення, що здійснюються для досягнення перекладацької еквівалентності (адекватності перекладу) всупереч розбіжностям у формальних і семантичних системах двох мов. Встановлено, що $є$ декілька причин їх застосування.

Ключові слова: політична промова, способи перекладу, стратегії перекладу, трансформації, проблеми перекладу. 